\title{
Rethinking informal learning
}

\author{
Francisco J. García-Peñalvo \\ GRIAL Research Group, \\ Educational Research Institute, \\ University of Salamanca \\ fgarcia@usal.es
}

\author{
David Griffiths \\ University of Bolton, UK \\ D.E.griffiths@bolton.ac.uk
}

\begin{abstract}
Informal learning has been always an important source of knowledge, perhaps the most important at the workplace, but its own informal nature has caused difficulties to be recognized and introduced in the "official" ways of training and certification. TEEM conference has paid special attention to the problems associated with informal learning from the first edition of this event, and now this track continues with this significant tradition with the aim of rethinking the informal learning basis.
\end{abstract}

\section{Categories and Subject Descriptors}

\section{K.3.1 [Computer Uses in Education]}

\section{General Terms}

Human Factors.

\section{Keywords}

Formal learning; Informal learning; Competence; Knowledge management

\section{INTRODUCTION}

Informal learning is an increasingly important element, specially at the workplace [7], that is focused for different international organizations. Informal learning visible seems to be at the forefront of a lot of public policy in the European Union and the OECD countries [18].

However, there is a mismatch between the enthusiasm of policy makers and other actors for initiatives to support the validation of informal learning, and the lack of adoption of systems in practice [12].

The promoters of this track have experienced this sensation before, especially in the development of the European project TRAILER (Tagging, Recognition, Acknowledgment of Informal Learning Experiences) project [8; 14], a KA3 European project devoted to advance in informal learning recognition by the learners and acknowledgement by the institutions, we have perceived some interesting approaches and behaviors regarding the informal learning.

\footnotetext{
Permission to make digital or hard copies of all or part of this work for personal or classroom use is granted without fee provided that copies are not made or distributed for profit or commercial advantage and that copies bear this notice and the full citation on the first page. Copyrights for components of this work owned by others than the author(s) must be honored. Abstracting with credit is permitted. To copy otherwise, or republish, to post on servers or to redistribute to lists, requires prior specific permission and/or a fee. Request permissions from Permissions@acm.org.

TEEM '15, October 07 - 09, 2015, Porto, Portugal

Copyright is held by the owner/author(s). Publication rights licensed to ACM.

ACM 978-1-4503-3442-6/15/10 ..\$15.00

DOI: http://dx.doi.org/10.1145/2808580.2808648
}

TRAILER had a special emphasis on promoting reflection on the individual's evidences of informal learning, this way every person, through a set of workflows and a tool-based support, could make visible these evidences, tagging them and associating them with a set of competences contained in a established catalogue. When an institution has access to the informal learning evidences of all its employees, the organization is able to make decisions and acknowledge the value of their informal learning activities. Through this process of making visible the informal learning by individuals and institutional recognition, TRAILER creates a bridge for communication and a win-win process between the institution and its staff. This approach, a priori, is easy to convey to the management levels and those that are responsible for the knowledge management, the intellectual capital and human resources of the institutions. However, as evidenced after the pilot TRAILER ecosystem [13] in real situations [17], this approach, although a frontal rejection of the system is not perceived, nor the importance of informal learning in the professional development of the individual and therefore the strategy corporate knowledge management, a major barrier is obseryed when introducing such solutions in the day-to-day professional activities. In fact, it shows that using a proposal based on a catalogue of competences makes very difficult the ultimate goal of the process, due to the validation of informal learning becomes an extension of the management processes of the formal educational processes.

These reflections from TRAILER project development are not out unique source, we have involved in other experiences such as TENCompetence project [1], which provided a set of tools to support lifelong learning, or Elvin, for language practice [10], among others. Thus, we may claim that informal learning is an increasingly important element in various fields, thus enhancing informal learning practices in formal contexts (informalization of formal learning) as somehow recognizing the knowledge, competencies and skills acquired informally (formalization of informal learning).

From the first edition of TEEM Conference $[5 ; 6]$ informal learning has been always included as core topic of one of the conference tracks $[9 ; 11]$. The pursued purpose of these tracks has been to analyze problems experienced with the validation of informal learning and to propose alternative approaches, especially the detected mismatch between the enthusiasm of policy makers and other actors for informal learning initiatives, and the lack of adoption of systems in real workplaces. The use of managerial tools, such as validation and competence catalogues, has demonstrated the danger of constraining the scope for informal learning. Also, we would like to advance and explore other different approaches to achieve the challenge of defining a very transparent framework in which both formal and informal learning are considering as important components of the own person's knowledge base, in other words, we would like to rethink the idea and importance of informal learning in current society.

In a more specific way, the topics covered in this track are: 
- Informal learning competences discovering and recognition.

- Technological ecosystem for enhancing informal learning recognition.

- Informal learning approaches in formal learning contexts.

- Semantic representations for informal learning evidences.

- Informal learning behaviors.

\section{TRACK ORGANIZATION}

This section describes in further detail the five contributions accepted to participate in this Conference track.

\subsection{Designing an Informal Learning Support Framework}

Informal learning, alongside competence-based learning and learning outcomes is getting a lot of attention lately. A large number of countries and organizations are busy defining guidelines for validating and evaluating informal learning experiences and formalizing its outcomes. In a globalized society where technology has brought together different cultures and educational systems, managing to keep track of a learner's competences is a daunting task, and especially when trying to take into account the competences acquired through informal means. Starting from their previous experiences in the creation of the Informal Learning Collector $[2 ; 3 ; 15]$ in the European Commission TRAILER project $[8 ; 14]$, authors propose a framework to gather, organize, evaluate and showcase a user's informal learning using a largely social approach.

\subsection{Semantic Similarity algorithm for SOAQ} assessment

In this paper, authors present an approach oriented to assist tutors in assessment of questions with open and short response by using concept maps for the answers and semantic similarity measures between the texts. This short answer assessment is based on the reference response prepared by the tutor. Following a knowledge base generation starting from the important concepts of the learner and tutor answers, we propose to compare them with a similarity measure to calculate and deliver a final score to the answer.

\subsection{Relationships between visual communication and informal learning}

The usage of visual communication is broadly extended nowadays; with the intensive usage of social networks based (partially or totally) on sharing images and visual representations, people has adopted this kind of communication as normal and develops new dimensions in the knowledge, understanding and communicating processes even without knowing clearly about this kind of communication. The usage of this visual signs and messages require some learning from the stakeholders involved in the communication, and it has observed that they learn usually in an informal way and mostly by imitating the communication patterns used by influential people. This paper explains the relationships between the current usage of visual communication and the informal learning, and how the learning of this kind of communication could be developed and what strategies can be followed to perform it in a effective way.

\subsection{Learning services-based technological ecosystems}

The gap between technology and learning methods has two important implications: on the one hand, we should not expect the integration of technological advances into teaching to be an easy task; and there is a danger that mature educational technologies and methods might not give an adequate answer to the demands and needs of society, underusing their transforming potential to improve learning processes. This paper discusses the need for a new technological environment supporting learning services, and proposes the concept of the technological learning ecosystem [4; 16] as a solution to both problems. Educational ecosystems should be able to break the technological constraints of existing learning platforms and achieve an effective improvement in learning processes. The proposed educational ecosystems pivot around five specific lines of action: 1) a framework architecture that supports learning service-based ecosystems; 2) learning analytics for educational decision making; 3) adaptive knowledge systems; 4) gamification of learning processes; 5) semantic portfolios to collect evidence of learning.

\subsection{Design of the survey instrument to evaluate innovation in healthcare centers}

This article describes the methodological procedure followed in the design and validation of the survey instrument applied among service Providers at First-level Assistance Centers - run by the Regional Healthcare Department (GERESA) in Lambayeque, Peru-with the aim to evaluate the factors that prevent them from making innovation. This survey instrument was designed to meet one of the specific objectives established on the research project entitled Potential Demand in the Research Conducted by University Professors in order to Increase the Technological Innovation in the Social and Productive Sectors in Lambayeque, Peru, $2014-2020$

\section{REFERENCES}

[1] Berlanga, A.J., Sloep, P.B., Brouns, F., Bitter-Rijpkema, M.E., and Koper, R., 2008. Towards a TENCompetence ePortfolio. International Journal of Emerging Technologies in Learning 3, 24-28.

[2] Galanis, N., Mayol, E., Alier, M., and García-Peñalvo, F.J., 2014. A Social Framework for Supporting, Evaluating and Validating Informal Learning. In Proceedings of the Second International Conference on Technological Ecosystems for Enhancing Multiculturality (TEEM'14), F.J. García-Peñalvo Ed. ACM, New York, USA, 589-594. DOI= http://dx.doi.org/10.1145/2669711.2669960.

[3] Galanis, N., Mayol, E., Alier, M., and García-Peñalvo, F.J., 2014. Validation of Informal Learning. In Proceedings of the Second International Conference on Technological Ecosystems for Enhancing Multiculturality (TEEM'14), F.J. García-Peñalvo Ed. ACM, New York, USA, 695-702. DOI= http://dx.doi.org/http://dx.doi.org/10.1145/2669711.266 9976.

[4] García-Holgado, A. and García-Peñalvo, F.J., 2014 Architectural pattern for the definition of eLearning ecosystems based on Open Source developments. In Proceedings of 2014 International Symposium on Computers in Education (SIIE), Logrono, La Rioja, Spain, 12-14 Nov. 2014, J.L. Sierra-Rodríguez, J.M. Dodero-Beardo and D. Burgos Eds. Institute of 
Electrical and Electronics Engineers, USA, 93-98. DOI= http://dx.doi.org/10.1109/SIIE.2014.7017711. García-Peñalvo, F.J., 2013. Proceedings of the First International Conference on Technological Ecosystems for Enhancing Multiculturality, TEEM 2013. ACM, New York, USA.

[6] García-Peñalvo, F.J., 2014. Proceedings of the Second International Conference on Technological Ecosystems for Enhancing Multiculturality, TEEM 2014. ACM, New York, USA.

[7] García-Peñalvo, F.J., Colomo-Palacios, R., and Lytras, M.D., 2012. Informal learning in work environments: training with the Social Web in the workplace. Behaviour \& Information Technology 31, 8, 753-755. $\mathrm{DOI}=$ http://dx.doi.org/10.1080/0144929X.2012.661548.

[8] García-Peñalvo, F.J., Conde, M.Á., Zangrando, V., García-Holgado, A., Seoane, A.M., Alier, M., Galanis, N., Brouns, F., Vogten, H., Griffiths, D., Mykowska, A., Ribeiro-Alves, G., and Minović, M., 2013. TRAILER Project (Tagging, Recognition, Acknowledgment of Informal Learning Experiences). A Methodology to Make Learners' Informal Learning Activities Visible to the Institutions. Journal of Universal Computer Science 19, 11, 1661-1683.

[9] García-Peñalvo, F.J., García-Holgado, A., and CruzBenito, J., 2013. Formal and informal learning experiences in multicultural scopes. In Proceedings of the First International Conference on Technological Ecosystems for Enhancing Multiculturality, F.J. GarcíaPeñalvo Ed. ACM, New York, USA, 523-527. DOI= http://dx.doi.org/10.1145/2536536.2536616.

[10] García-Peñalvo, F.J., González-González, J.C., and Murray, M., 2012. MyElvin: A Web-Based Informal Learning Platform for Languages Practice. International Journal of Knowledge Society Research 3, 1, 26-39.

[11] García-Peñalvo, F.J. and Griffiths, D., 2014. Transferring knowledge and experiences from informal to formal learning contexts. In Proceedings of the Second International Conference on Technological Ecosystems for Enhancing Multiculturatity/(TEEM'14), F.J. García-Peñalvo Ed. ACM, New York, USA, 569572 . DOI= http://dx.doi.org/http://dx.doi.org/10.1145/2669711.266 9957.

[12] García-Peñalvo, F.J., Griffiths, D., Jonhson, M., Sharples, P., and Sherlock, D., 2014. Problems and opportunities in the use of technology to manage informal learning. In Proceedings of the Second International Conference on Technological Ecosystems for Enhancing Multiculturality (TEEM'14), F.J. GarcíaPeñalvo Ed. ACM, New York, USA, 573-580. DOI= http://dx.doi.org/http://dx.doi.org/10.1145/2669711.266 9958.

[13] García-Peñalvo, F.J., Johnson, M., Ribeiro Alves, G., Minovic, M., and Conde-González, M.Á., 2014. Informal learning recognition through a cloud ecosystem. Future Generation Computer Systems 32, 282-294. DOI= http://dx.doi.org/http://dx.doi.org/10.1016/j.future.2013. $\underline{08.004}$.

[14] García-Peñalvo, F.J., Zangrando, V., García-Holgado, A., Conde, M.Á., Seone Pardo, A.M., Alier Forment, M., Janssen, J., Griffiths, D., Mykowska, A., Ribeiro Alves, G., and Minovic, M., 2012. TRAILER project overview: Tagging, recognition and acknowledgment of informal learning experiences. In Proceedings of the 2012 International Symposium on Computers in Education (SIIE) (Andorra La Vella, Andorra. October 29-31, 20122012), Institute of Electrical and Electronics Engineers.

[15] García-Peñalvo, F.J., Zangrando, V., García-Holgado, A., Conde-González, M.Á., Seoane-Pardo, A.M., Alier, M., Galanis, N., López, J., Janssen, J., Brouns, F., Finders, A., Berlanga, A., Sloep, P., Griffiths, D., Johnson, M., Waszkiewicz, E., Mykowska, A., Minovic, M., Milovanovic, M., Marques, M.A., Viegas, M.C., and Alves, G., 2013. A Tool to Aid Institutions Recognize Their Employees Competences Acquired by Informal Learning. In Scaling up Learning for Sustained Impact. 8th European Conference onTechnology Enhanced Learning,EC-TEL2013. Paphos, Cyprus, September 17-21, 2013 Proceedings (Paphos, Cyprus, September 17-21, 2013), D. Hernández-Leo, T. Ley, R. Klamma and A. Harrer Eds. Springer Verlag, Berlin, Heidelberg, 552-555. DOI= http://dx.doi.org/10.1007/978-3-642-40814-4 56.

[16] Llorens, F., Molina, R., Compañ, P., and Satorre, R., 2014. Technological Ecosystem for Open Education. In Smart Digital Futures 2014., R. Neves-Silva, G.A. Tsihrintzis, V. Uskov, R.J. Howlett and L.C. Jain Eds. IOS Press, 706-715.

[17] Viegas, C., Marques, M., Alves, G., Mykowska, A., Galanis, N., Alier, M., Brouns, F., Janssen, J., GarcíaPeñalvo, F.J., García-Holgado, A., Zangrando, V., and Conde-González, M.A., 2014. TRAILER - a Tool for Managing Informal Learning. International Journal of Human Capital and Information Technology Professionals (IJHCITP) 5, 3, 1-17. DOI= http://dx.doi.org/10.4018/ijhcitp.2014070101.

[18] Werquin, P., 2008. Recognition of non-formal and informal learning in OECD countries:A very good idea in jeopardy? Lifelong Learning in Europe 2008, 3, 4249. 